\title{
Pengaruh Pemberian Aromaterapi Terhadap Konsentrasi Siswa Kelas V Sekolah Dasar dalam Mengerjakan Soal Ulangan Umum
}

\author{
Ni Made Yanthi Ary Agustini dan Hilda Sudhana \\ Program Studi Psikologi, Fakultas Kedokteran, Universitas Udayana \\ yanthiarya@gmail.com
}

\begin{abstract}
Abstrak
Aromaterapi di dalam kehidupan masyarakat Bali sangat lekat. Aromaterapi memiliki pengaruh terhadap fungsi dalam tubuh diantaranya membuat udara dalam ruangan menjadi segar, menciptakan suasana yang tenang, dapat digunakan sebagai antibiotik, dapat berguna menjadi antiseptik untuk melakukan perlawanan terhadap virus, merendam emosi, dapat menjadi alat untuk relaksasi, dan juga meningkatkan konsentrasi. Di dalam dunia pendidikan konsentrasi merupakan suatu hal yang sangat penting salah satunya dalam mengerjakan ulangan umum. Penelitian ini bertujuan untuk membuktikan apakah benar terdapat pengaruh pemberian aromaterapi terhadap konsentrasi anak kelas $\mathrm{V}$ sekolah dasar dalam mengerjakan soal-soal ulangan umum.

Penelitian ini merupakan penelitian kuantitatif dengan metode pre-eksperimen, teknik sampling yang digunakan yaitu cluster random sampling. Subjek pada penelitian ini adalah siswa kelas V sekolah dasar yang sedang mengikuti ulangan umum di SD Negeri 5 Tonja sebanyak 82 siswa. Pengumpulan data menggunakan kuesioner konsentrasi dengan skala Likert. Selanjutnya dianalisa menggunakan uji independent sample t-test.

Setelah melakukan uji validitas dan reliabilitas terdapat 25 item yang tersisa dari total 34 item yang ada dengan koefisien reliabilitas sebesar 0,876 . Setelah melakukan uji independent sample t-test diperoleh nilai signifikansi $\mathrm{p}$ sebesar $0,823(>0,05)$. Hal ini berarti tidak terdapat pengaruh pemberian aromaterapi terhadap konsentrasi anak kelas V sekolah dasar dalam mengerjakan soal-soal ulangan umum. Berdasarkan data tambahan yang melihat konsentrasi setiap harinya, terdapat peningkatan konsentrasi pada siswa kelompok eksperimen, namun belum mencapai titik signifikan.
\end{abstract}

Kata kunci : Aromaterapi, Konsentrasi, Siswa, Ulangan Umum

\begin{abstract}
Aromatherapy in Balinese life very closely. Aromatherapy has an influence on the function of the body such as making a fresh indoor air, creating a calm, can be used as antibiotics, antiseptics may be useful to take the fight against the virus, soaking emotion, can be a tool for relaxation, and also improves concentration. Concentration in the world of education is a very important one in doing general replications. This study aimed to verify whether there are effects of aromatherapy to the concentration of children in the fifth grade of primary school working on the general test questions.

This research is a quantitative study with pre-experimental methods, sampling technique used is cluster random sampling. Subjects in this study were fifth grade elementary school students who are following the general replication at SD Negeri 5 Tonja by 82 students. Collecting data using a concentration questionnaire with Likert scale and data analysis by independent sample t-test.

After conducting validity and reliability there are 25 items left from a total of 34 items on the reliability coefficient of 0.876. After doing the independent sample t-test significance $\mathrm{p}$ values obtained for 0.823 (>0.05). This means there is no effect of aromatherapy to the concentration of children in the fifth grade of primary school working on the general test questions. Based on additional data to see the concentration of each day, there is an increasing concentration in the experimental group students, but has not reached a significant point.
\end{abstract}

Keywords: Aromatherapy, Concentration, Students, General Test 


\section{LATAR BELAKANG}

Bali merupakan sebuah pulau yang terkenal dengan pariwisata. Menurut Subastianwibowo (2012) Bali menempati posisi pertama sebagai objek wisata terpopuler di Indonesia pada tahun 2012. Jenis wisata yang ditawarkan pun beragam mulai dari wisata budaya, wisata alam, wisata belanja, dan masih banyak lagi yang lainnya. Wisata alam yang terdapat di Pulau Bali adalah menyuguhkan keindahan-keindahan alam yang ada seperti pantai, pegunungan, dan juga bukit. Sedangkan wisata belanja yang ditawarkan kepada wisatwan yaitu barang-barang seni buatan pengerajin lokal seperti patung, lukisan, dan aneka jenis kerajinan yang lainnya. Sedangkan wisata budaya dengan mengangkat budaya lokal berbasis Agama Hindu seperti seni pertunjukan. Salah satu aset yang dimiliki pulau Bali untuk ditawarkan kepada dunia pariwisata ialah aroma atau wewangian yang disebut dengan aromaterapi. Aromaterapi dibuat menggunakan bahan cairan tanaman yang mudah menguap, dikenal sebagai minyak esensial senyawa aromatik lainnya dari tumbuhan. Menurut Henderson (2007) aromaterapi merupakan minyak atsiri yang mampu mempengaruhi individu baik secara fisiologis maupun psikologis. Menurut Femina (2010) terdapat beberapa bentuk aromaterapi yaitu dupa, lilin, dan juga minyak esensial. Dupa biasanya terbuat dari akar-akar yang harum kemudian dihancurkan untuk dijadikan bubuk dupa, sedangkan lilin aromaterapi biasanya berbahan minyak esesnsial sehingga ketika dibakar lilin tersebut akan mengeluarkan aroma yang harum. Minyak esensial sendiri biasanya digunakan tungku yang dibawahnya berisi lilin sebagai alat pemanas ataupun tungku elektrik yang menggunakan listrik.

Aromaterapi di dalam kehidupan masyarakat Bali sangat lekat. Hal tersebut dapat dilihat dari rutinitas yang dilakukan, khususnya pada kegiatan ritual yang dilakukan oleh pemeluk agama Hindu. Setiap ritual keagamaan yang dilakukan selalu menggunakan dupa dan tentunya dupa ini adalah salah satu bentuk dari aromaterapi. Dupa merupakan sejenis harum-haruman yang dibakar sehingga berasap dan mengeluarkan bau yang harum (Sudirga, 2007). Dupa merupakan sarana persembahyangan yang harus ada ketika upacara keagamaan berlangsung yang merupakan simbolis dari api. Dupa dengan nyala apinya memiliki beberapa fungsi yaitu: 1) sebagai pemimpin upacara, 2) sebagai sarana perantara yang menghubungkan pemuja dengan yang dipuja, dan 3) sebagai saksi upacara dalam kehidupan (Sudirga, 2007).

Selain digunakan sebagai sarana persembahyangan, masyarakat Bali menggunakan aromaterapi sebagai salah satu bahan dalam produk perawatan tubuh yang ditawarkankepada wisatawan yang berkunjung ke Bali berupa spa atau body treatment. Spa di Bali merupakan salah satu bagian dari pariwisata yang sangat terkenal di mata dunia. Hal ini ditunjukan dengan predikat sepuluh besar spa terbaik di dunia
(Suardana, 2009). Banyak wisatawan memanfaatkan jasa ini untuk menyegarkan kembali tubuh yang sudah lelah. Spa ini merupakan salah satu bentuk perawatan diri dengan menggunakan aromaterapi baik pada pemijatan maupun untuk pengharum ruangan. Pemijatan atau body massage yang dilakukan bertujuan untuk melemaskan otot-otot atau relaksasi yang ditambah dengan aromaterapi tentu saja akan membuat pikiran tenang dan tubuh menjadi rileks.

Aromaterapi juga terkadang digunakan sebagai salah satu alat relaksasi. Gaya hidup pada zaman sekarang yang setiap harinya sibuk dan memiliki waktu yang terbatas menjadikan waktu bersantai sangat jarang didapatkan. Terapi dengan aroma dapat sebagai salah satu cara efektif untuk relaksasi, menghilangkan stres dan menenangkan pikiran (Hastianingsih, 2013). Aromaterapi dijadikan sebagai pengharum ruangan di dalam ruangan untuk mengurangi stres akibat rutinitas sehari-hari.

Di sisi lain, menurut beberapa tokoh aromaterapi dikatakan memiliki pengaruh terhadap fungsi dalam tubuh. Menurut Shah, Sen, Patel, Patel, Patel, dan Prajapati (2011), aromaterapi yang dihirup melalui hidung, akan menuju saraf olfaktori yang berada di dalam rongga hidung, selanjutnya akan menuju bagian dari otak yang mengatur emosi, memori serta kemampuan belajar dan tempat ini disebut sebagai sistem limbic. Aromaterapi memiliki dampak tidak hanya pada aspek fisik tetapi juga pada aspek psikologis.Menurut Henderson (2007), aromaterapi memiliki beberapa fungsi diantaranya membuat udara dalam ruangan menjadi segar, menciptakan suasana yang tenang, dapat digunakan sebagai antibiotik, dapat berguna menjadi antiseptik untuk melakukan perlawanan terhadap virus, merendam emosi, dapat menjadi alat untuk relaksasi, dan juga meningkatkan konsentrasi. Tidak jauh berbeda dengan pendapat Henderson, berdasarkan penelitian yang dilakukan oleh Hongratanaworakit (2004), ditemukan bahwa aromaterapi memberikan efek yang signifikan pada gelombang otak, hal tersebut dilihat dari hasil EEG. Hasil dari amplitudo serta frekuensi menunjukkan bahwa adanya aktivitas pada gelombang alpha, betha, serta tetha. Ketika individu sedang membaca atau pada saat pikiran berkonsentrasi, gelombang betha adalah gelombang dominan dan alpha dihambat. Penelitian lain juga dilakukan terhadap anak autis serta kesulitan belajar dengan pijatan menggunakan aromaterapi (Solomons, 2005). Melalui pemijatan, aromaterapi juga dihirup oleh subjek dan hasilnya subjek dapat meningkatkan perhatiannya. Dari beberapa penelitian yang telah dilakukan di atas, dapat disimpulkan bahwa aromaterapi memiliki fungsi untuk meningkatkan konsentrasi.

Menurut Winkel (dalam Ratnasari 1987) dalam proses belajar pada dunia pendidikan konsentrasi merupakan salah satu aspek penting. Oleh karena itu konsentrasi merupakan salah satu faktor yang harus diperhatikan, 
utamanya ketika mengerjakan soal- soal ulangan umum. Konsentrasi dibutuhkan pada saat mendengarkan penjelasan guru, memahami materi yang diberikan, dan mengerjakan tugas-tugas di sekolah sehingga dicapai hasil belajar yang maksimal. Demi mencapai hasil belajar yang maksimal, konsentrasi juga diperlukan dalam mengerjakan ulangan umum. Konsentrasi yang dimaksudkan disini adalah konsentrasi yang merupakan fokus perhatian siswa ketika mengerjakan ulangan yang dilakukan pada saat ulangan umum berlangsung di dalam kelas.

Siswa dapat berkonsentrasi dengan baik dipengaruhi oleh dua faktor, yaitu faktor internal dan eksternal (Susanto, 2006). Faktor internal adalah faktor yang muncul dalam diri anak itu misalnya kesiapan siswa dalam menerima pelajaran, kondisi fisik seperti kondisi tubuh yang sehat atau tidak sakit, kondisi psikologis siswa tidak stres, modalitas belajar atau yang sering disebut dengan gaya belajar. Sedangkan faktor eksternal adalah pengaruh yang berasal dari luar individu misalnya adanya gangguan dari lingkungan seperti suara dan juga bau atau aroma. Konsentrasi dalam mengerjakan ulangan merupakan indikator bahwa siswa mampu untuk fokus dalam mengerjakan soal-soal ulangan umum sehingga didapatkan hasil yang optimal. Hasil yang optimal ini ditunjukkan dengan nilai yang baik.

Berdasarkan hasil wawancara yang sempat peneliti lakukan terhadap beberapa siswa yang sedang duduk di kelas V sekolah dasar, diperoleh kesimpulan bahwa makin tinggi jenjang kelas maka konsentrasi yang diperlukan untuk belajar mengalami peningkatan. Hal ini disebabkan materi yang diajarkan mengalami peningkatan salah satunya dari segi menghapal. Pada kelas V sekolah dasar selain materi pelajaran yang diberikan bertambah sulit, bahasa yang digunakan pada saat ulangan berlangsung mengalami peningkatan tingkat kesulitan. Sehingga tidak jarang mereka kurang mengerti maksud dari soal jika tidak berkonsentrasi penuh pada setiap soal yang. Akibatnya, beberapa mata pelajaran yang dianggap mampu dikerjakan, tetapi malah menghasilkan hasil atau nilai yang kurang memuaskan.

Berdasarkan pertimbangan tersebut maka peneliti ingin mengetahui apakah benar aromaterapi dapat mempengaruhi konsentrasi siswa khususnya pada saat mengerjakan soal-soal ulangan ulangan umum. Penelitian ini diharapkan dapat menambah pengetahuan dalam ilmu psikologi, khususnya psikologi pendidikan yang terkai dengan konsentrasi dalam belajar. Manfaat praktis dari penelitian ini yaitu aromaterapi dapat menjadi alternatida dalam meningkatkan konsentrasi siswa, sehingga baik dari pihak guru maupun sekolah nantinya akan menggunakan aromaterapi dalam proses belajar mengajar di sekolah. Bagi orang tua aromaterapi dapat digunakan sebagai alat yang mampu menciptakan ketenangan dalam belajar di rumah.

\section{METODE}

\section{Hipotesis Penelitian}

Hipotesis penelitian merupakan sebuah jawaban sementara yang ditetapkan oleh peneliti terhadap masalah yang ditelitinya (Suryabrata, 2000). Berdasarkan hal tersebut, maka hipotesis dalam penelitian ini adalah hipotesis alternatif (Ha) ada pengaruh pemberian aromaterapi terhadap konsentrasi siswa kelas V sekolah dasar ketika mengerjakan soal ulangan pada saat ulangan umum berlangsung. Seadangkan, hipotesis nol (H0) tidak ada pengaruh pemberian aromaterapi terhadap konsentrasi siswa kelas $\mathrm{V}$ sekolah dasar ketika mengerjakan soal ulangan pada saat ulangan umum berlangsung.

\section{Variabel dan definisi operasional}

Variabel penelitian adalah segala sesuatu yang berbentuk apa saja yang ditretapkan oleh peneliti untuk dipelajari sehingga diperoleh informasi mengenai hal tersebut dan selanjutnya dapat ditarik kesimpulan mengenai hal yang diteliti (Sugiyono, 2012). Menurut Sugiyono (2012) variabel bebas sering disebut sebagai variabel stimulus, prediktor, atau antecendent dan variabel tergantung merupakan variabel yang dipengaruhi atau yang menjadi akibat, karena adanya perlakuan pada variabel bebas. Variabel bebas dalam penelitian ini adalah aromaterapi, sedangkan variabel tergantungnya adalah konsentrasi.

Definisi operasional dari pemberian aromaterapi adalah suatu teknik pemberian wangi-wangian yang berupa minyak essensial yang berasal dari tumbuhan. Aroma yang digunakan pada penelitian ini adalah aroma peppermint. Metode yang digunakan dalam penelitian ini adalah dengan menghirup aroma peppermint ketika ulangan umum mata pelajaran pertama berlangsung di dalam kelas selama kurang lebih 120 menit. Bentuk dari aromaterapi yang digunakan adalah pengharum ruangan yang menggunakan tungku, di dalamnya berisi sebuah lilin sebagai alat bakar dan diatasnya diisi dengan air hangat, lalu ditetesi aromaterapi dengan essence peppermint sebanyak 10-12 tetes.

Definisi operasional dari konsentrasi siswa yaitu situasi ketika siswa fokus pada apa yang dikerjakan pada saat ulangan umum berlangsung. Indikator yang digunakan untuk mengukur konsentrasi siswa dalam mengerjakan ulangan umum adalah 1) pemusatan perhatian, 2) merespon serta memahami pertanyaan, 3) sensasi, 4) kesadaran untuk mencapai hasil yang maksimal, 5) durasi. Konsentrasi siswa nantinya akan diukur menggunakan kuesioner yang terdiri dari 34 pernyataan. Item-item pernyataan yang dibuat menggunakan Skala Likert. 


\section{N. M. Y. A. AGUSTINI DAN H. SUDHANA}

\section{Respoanden}

Populasi pada penelitian ini adalah siswa kelas V sekolah dasar negeri di Kota Denpasar. Selanjutnya subjek dipilih secara random agar setiap orang mendapatkan kesempatan yang sama untuk menjadi subjek penelitian. Metode pengambilan sample yang digunakan adalah cluster sampling. Sehingga peneliti menetapkan siswa kelas V sekolah dasar pada SD Negeri 5 Tonja sebagai subjek penelitian. Subjek pada penelitian ini adalah siswa kelas V sekolah dasar, di SD Negeri 5 Tonja yang terdiri dari dua kelas yaitu kelas A dan kelas B. Satu kelas sebagai kelompok eksperimen yaitu kelas A dengan diberikan aromaterapi yang beraroma peppermint ketika ulangan umum pada mata pelajaran pertama berlangsung. Setelah selesai mengerjakan soal-soal yang ada para siswa akan diberikan kuesioner yang mengukur konsentrasi mereka selama proses pengerjaan ulangan umum berlangsung. Satu kelas lagi yaitu kelas B sebagai kelompok kontrol, dengan tidak diberikan aromaterapi ketika ulangan umum pada jam pertama berlangsung. Sama seperti kelompok eksperimen, setelah selesai mengerjakan soal-soal ulangan umum yang ada, siswa akan diberikan kuesioner untuk mengetahui konsentrasi ketika mengerjakan soal- soal yang ada namun tanpa diberikannya aromaterapi di dalam ruang kelas. Hal ini dilakukan oleh peneliti dengan tujuan ingin mengetahui apakah terdapat perbedaan konsentrasi ketika mengerjakan soal-soal ulangan umum pada kelompok yang diberikan aromaterapi dengan kelompok yang tidak diberikan aromaterapi.

\section{Tempat penelitian}

Responden dalam penelitian ini adalah siswa kelas $\mathrm{V}$ sekolah dasar yang sedang mengikuti ulangan umum di Kota Denpasar. Oleh karena itu, peneliti mengambil sebuah sekolah secara acak dengan kriteria tertentu yaitu: sekolah memiliki dua kelas yang paralel. Maka terpilihlah SD Negeri 5 Tonja sebagai tempat dilakukannya penelitian. Dalam menentukan jumlah sampel yang digunakan pada penelitian ini digunakan rumus Pocock (Pocock, 1983) sehingga diperoleh hasil minimal jumlah sampel sebanyak 65 orang siswa.

\section{Alat ukur}

Kuesioner digunakan untuk mengukur konsentrasi belajar. Kuesioner terdiri dari 34 item pernyataan yang mengukur tentang konsentrasi. Menggunakan skala Likert dengan rentang: sangat tidak setuju, tidak setuju, setuju, sangat setuju. Nilai tertinggi pada item yang berisikan pernyataan favorable adalah 4 dan nilai terendah adalah 1 , sedangkan nilai tertinggi pada item dengan pernyataan unfavorable adalah 1 dan nilai terendah adalah 4. Kuesioner yang diberikan berbentuk cek list, setiap pernyataan yang sesuai akan diberi ceklist pada kolom disebelahnya.

\section{Prosedur pengambilan data}

Penelitian ini merupakan penelitian kuantitatif yang menggunakan metode pra- experimental design yaitu static group comparison. Menurut Suryabrata (2000), pada rancangan ini, subjek dibagi menjadi dua kelompok secara rambang, yaitu kelompok eksperimen dan kelompok kontrol. Kelompok eksperimen merupakan kelompok yang mendapatkan perlakuan, sedangkan kelompok kontrol adalah kelompok yang tidak dikenai perlakuan namun dan pada akhirnya kedua kelompok tetap mendapatkan kuesioner sebagai alat pengukuran. Perbedaan yang nantinya timbul dianggap bersumber pada perlakuan yang diberikan selama penelitian berlangsung (Suryabrata, 2000).

Dalam penelitian ini, terdapat dua kelompok yang digunakan, kelompok pertama merupakan kelompok eksperimen yang nantinya diberikan aromaterapi ketika ulangan umum berlangsung dan diakhir jam pelajaran tersebut kelompok akan diberikan kuesioner untuk mengukur tingkat konsentrasi subjek selama ulangan berlangsung. Kelompok kedua merupakan kelompok kontrol, kelompok ini tidak diberikan perlakuan atau dengan kata lain ketika ulangan umum berlangsung, kelompok tidak diberi aromaterapi, dan kemudian diakhir jam pelajaran kelompok ini akan diberikan kuesioner untuk mengukur tingkat konsentrasi subjek. Metode ini digunakan untuk mengetahui sejauh mana perbedaan yang terjadi pada kelompok yang menggunakan aromaterapi dan kelompok yang tidak menggunakan aromaterapi.

Berikut ini tata pelaksanaan penelitian yang dilakukan

1. Menentukan kelas yang dijadikan kelompok eksperimen dan juga kelompok kontrol secara acak.

2. Kelompok kontrol adalah kelompok yang tidak mendapatkan perlakuan.

3. Kelompok eksperimen adalah kelompok yang mendapat perlakuan. Pada kelompok eksperimen dilakukan tahap sebagai berikut.

- Sebelum siswa masuk ke dalam kelas, peneliti menyalakan aromaterapi.

- Menyiapkan aromaterapi dengan membakar lilin terlebih dahulu, lalu meletakannya ke dalam tungku. Ketika lilin sudah menyala kemudian cawan ditempatkan di atas tungku. Cawan kemudian dituangi air hangat yang selanjutnya ditetesi 10-12 tetes aroma peppermint.

- Sesudah aroma menyebar secara merata keseluruh ruangan kelas, siswa kemudian masuk.

- Guru membagikan lembar soal serta lembar jawaban kepada siswa untuk menjawab pertanyaan.

4. Setelah kurang lebih selama 120 menit waktu yang diberikan untuk mengerjakan soal selesai, kemudian siswa baik pada kelompok eksperimen dan kelompok kontrol akan diberikan kuesioner. 


\section{Teknik Analisis Data}

Validitas suatu tes atau instrumen pengukuran dapat dikatakan mempunyai validitas yang tinggi apabila alat tersebut menjalankan fungsi ukurnya, atau memberikan hasil ukur yang sesuai dengan maksud yang dilakukannya pengukuran tersebut (Azwar, 2010). Pada penelitian ini validitas yang diukur adalah validitas konstruk, pengujian validitas dilakukan dengan mencari koefisien korelasi item total (rix) yang dibantu perangkat lunak SPSS 17.0. Suatu item dinyatakan memiliki validitas yang baik dapat diketahui menggunakan tabel product moment correlation untuk mengetahui skor $r$ hitung lalu dibandingkan dengan nilai kritis korelasi pearson atau disebut juga sebagai $r$ tabel atau item dapat dinyatakan valid apabila nilai $r$ hitung $>r$ tabel (Nurgiyantoro, Gunawan, \& Marzuki, 2004). Instrumen dinyatakan valid dengan melihat hasil koefisien korelasi item total sebesar 0,220 , jika item menyatakan tanda negatif (-) dan di bawah 0,220 item tersebut dinyatakan gugur dan tidak layak pakai (Azwar, 2010). Pada penelitian ini validitas yang diukur adalah validitas konstruk karena peneliti hendak mengukur tingkat konsentrasi pada siswa kelas $\mathrm{V}$ sekolah dasar.

Reliabilitas merupakan penerjemahan dari kata reliability yang mempunyai asal kata rely dan ability. Pengukuran yang memiliki reliabilitas tinggi disebut sebagai pengukuran yang reliabel (reliabel). Walaupun reliabilitas mempunyai berbagai nama lain seperti keterpercayaan, keterandalan, keajegan, kestabilan, konsistensi, dan sebagainya, namun dari semua itu memiliki sebuah ide pokok yang terkandung dalam konsep reliabilitas adalah sejauhmana hasil suatu pengukuran dapat dipercaya (Azwar, 2010). Pada penelitian ini uji reliabilitas menggunakan alpha cronbach's dengan bantuan perangkat lunak SPSS 17.0. Suatu alat ukur dinyatakan memiliki reliabilitas yang baik apabila nilai alpha yang diperoleh lebih besar dari 0,6.

Analisis data pada penelitian ini menggunakan metode analisis parametrik dengan independent-sample $t$ test. Independent-sample $\mathrm{t}$ tes digunakan untuk menguji signifikansi beda rata-rata dua kelompok. Tes ini biasanya digunakan untuk menguji pengaruh satu variabel independent terhadap satu atau lebih variabel dependent (Trihendradi,

2011). Dalam penelitian ini, analisis data menggunakan SPSS versi 17 untuk melihat perbedaan antara kedua kelompok. Sebelum melakukan uji ini, terdapat dua syarat yang harus dipenuhi, yaitu: uji homogenitas dan uji normalitas. Uji normalitas dan homogenitas yang dilakukan dengan batuan SPSS versi 17. Uji distribusi normal adalah uji untuk mengukur data memiliki distribusi normal atau tidak, sehingga dapat dipakai dalam statistik parametrik (statistik inferensial). Uji normalitas digunakan untuk menguji apakah variabel tergantung, variabel bebas, atau keduanya mempunyai distribusi normal atau tidak (Sugiyono, 2012). Pada penelitian ini uji normalitas menggunakan rumus Kolmogorov- Smirnov menggunakan SPSS versi 17. Data dikatakan berdistribusi normal apabila nilai $\mathrm{p}>0,05$ (Sugiyono, 2012). Uji homogenitas dimaksudkan untuk memperlihatkan bahwa dua atau lebih kelompok data sampel berasal dari populasi yang memiliki variansi yang sama (Darmadi, 2011). Pada penelitian ini, peneliti menggunakan Levene's Test of Equality of Error Variances dengan menggunakan SPSS versi 17 untuk menguji homogenitas data yang ada. Data dikatakan homogen apabila signifikansi yang diperoleh lebih besar dari 0,05, maka variansi setiap sampel sama atau homogen (Darmadi, 2011).

\section{HASIL PENELITIAN}

Pengambilan data dalam uji coba ini dilakukan dengan menyebarkan kuesioner ke dua kelas yang ada di SD Negeri 5 Tonja. Penelitian dilakukan selama empat hari yaitu pada tanggal 26 hingga 29 November 2012. Uji coba alat ukur secara langsung atau yang disebut dengan try out terpakai. Try out terpakai dilakukan oleh peneliti karena waktu yang diperlukan tidak memungkinkan peneliti untuk mengambil data dua kali, mengingat peneliti mengambil setting penelitian pada saat ulangan umum berlangsung. Data yang digunakan untuk uji coba alat ukur adalah data yang berasal dari kuesioner hari pertama. Subjek dalam penelitian ini adalah siswa kelas $\mathrm{V}$ yang terdiri dari dua kelas yaitu kelas $\mathrm{A}$ dan kelas B serta sedang mengerjakan soal ulangan umum. Kelas yang ditetapakan sebagai kelompok eksperimen adalah kelas A dan kelompok kontrol adalah kelas B. Uji coba penelitian ini dilakukan dengan menyebarkan kuesioner kepada 82 orang responden. Data tersebut kemudian dianalisis untuk mengetahui validitas dan reliabilitasnya.

Pengambilan data dilaksanakan dengan menyebarkan kuesioner mengenai konsentrasi siswa yang terdiri dari 34 item dengan 5 skala yang dilihat mengenai konsentrasi yaitu pemusatan perhatian, merespon serta memahami pertanyaan, sensasi, kesadaran untuk mencapai hasil yang maksimal, dan durasi. Melalui uji kesahihan item yang dilakukan pada skala konsentrasi diperoleh koefisien korelasi yang bergerak dari -0,304 hingga 0,621. Dari total jumlah 34 item, kemudian gugur sebanyak sembilan item. Sehingga item pada skala konsentrasi yang sahih menjadi 25 item. Setelah item yang ada berkurang maka hasil dari uji kesahihan item yang diperoleh koefisien korelasi yang bergerak dari 0,243 hingga 0,701 .

Reliabilitas dengan menggunakan Alpha Cronbach pada skala konsentrasi dengan jumlah subjek sebanyak 81 orang berasal dari kelas A dan kelas B. Nilai alpha ( $\square$ ) 0,729 ketika jumlah item yang diuji sebanyak 34 item. Setelah itu 
diuji kembali, item yang sahih kemudian menjadi 25 item dengan nilai alpha $(\square)$ sebesar 0 , 876. Alpha $(\alpha)$ sebesar 0,876 ini menunjukkan bahwa skala ini mampu mencerminkan $87,60 \%$ variasi yang terjadi pada skor murni subjek yang bersangkutan sehingga dapat digunakan untuk mengukur atribut yang dimaksudkan, yaitu konsentrasi. Berdasarkan hasil koefisien korelasi yang diperoleh, maka skala konsentrasi ini memiliki daya keterandalan yang cukup tinggi. Sebelum melakukan uji analisis data menggunakan idependent sampel t test, maka dilakukan uji normalitas untuk mengetahui distribusi atau persebaran data penelitian apakah normal atau tidak. Berdasarkan dari hasil uji normalitas yang diperoleh nilai (p) sebesar 0,528 atau p>0,05 sehingga data yang ada berdistribusi normal. Kemudian dilakukan uji homogentas pada data yang ada untuk mengetahui varian skor sebuah variabel yang diukur pada setiap kelompok yang diuji relatif homogen atau tidak. Dari hasil pengujian yang telah dilakukan diperoleh, sebaran data pada variabel konsentrasi memiliki nilai signifikansi dengan probabilitas $(\mathrm{p})=0,457$ atau memiliki nilai probabilitas diatas 0,05 ( $p>0,05)$. Sehingga dapat dilihat bahwa hal ini menunjukkan data pada variabel konsentrasi bersifat homogen.

Setelah kedua syarat untuk melakukan analisis data telah dipenuhi, dilanjutkan dengan menggunakan metode analisis independent samples test dengan alat bantu perangkat lunak SPSS 17.0.

Tabel.1

Hasil uji t

\begin{tabular}{cc}
\hline Keterangan & Nilai \\
\hline Uji Homogenitas & \\
Levene's Test & \\
Nilai F & 0.560 \\
Nilai Sig. & 0.457 \\
\hline Uji T & \\
Nilai Sig. (2-tailed) & 0.823 \\
\hline
\end{tabular}

Berdasarkan atas pedoman dalam menolak atau menerima hipotesis jika nilai $\mathrm{p}$ yang diberoleh lebih kecil dari $0,05(\mathrm{p}<0,05)$ maka hipotesis nol $(\mathrm{H} 0)$ yang telah ditetapkan ditolak, sehingga hipotesis alternatif $(\mathrm{Ha})$ yang ditetapkan akan diterima. Sedangkan pada penelitian ini diperoleh nilai $\mathrm{p}$ sebesar 0,823 atau ( $\mathrm{p}>0,05)$ maka hipotesis alternatif yang ada ditolak dan hipotesis nol yang ada diterima. Jadi hipotesis yang diterima berbunyi "tidak ada pengaruh pemberian aromaterapi terhadap konsentrasi siswa kelas V sekolah dasar ketika mengerjakan soal ulangan pada saat ulangan umum berlangsung".

Terkait dengan tidak ada pengaruh pemberian aromaterapi terhadap konsentrasi siswa kelas V sekolah dasar ketika mengerjakan soal ulangan pada saat ulangan umum berlangsung, maka dapat diketahui skor yang diperoleh dari setiap siswa dengan kategori yang ada. Pengkategorian ini dilakukan dengan menggunakan rumus pengkategorian skor dari Azwar (2000).

\begin{tabular}{cccc}
\multicolumn{4}{c}{ Tabel.2 } \\
& Kategori skor konsentrasi & \\
\hline Nilai & Kategori & Jumlah & Persentase \\
\hline $\mathrm{X} \leq 276,61$ & Sangat Rendah & 4 orang & $4,9 \%$ \\
\hline $276,61<\mathrm{X} \leq 304,44$ & Rendah & 25 orang & $30,5 \%$ \\
\hline $304,44<\mathrm{X} \leq 332,27$ & Sedang & 31 orang & $37,8 \%$ \\
\hline $332,27<\mathrm{X} \leq 360,10$ & Tinggi & 14 orang & $17,1 \%$ \\
\hline $360,10<\mathrm{X}$ & Sangat Tinggi & 8 orang & $9,8 \%$ \\
\hline
\end{tabular}

Dari tabel di atas diketahui jumlah siswa paling banyak berada di kategori sedang yaitu sebesar 37,8\%. Kategori sangat rendah dan kategori rendah jika dijumlah total yang diperoleh yaitu 35,4\% lebih besar dari kategori tinggi dan sangat tinggi yang berjumlah $28,9 \%$.

\section{PEMBAHASAN DAN KESIMPULAN}

Dilihat dari hasil perbandingan antara kelompok eksperimen dan kelompok kontrol dengan menggunakan uji independent sampel t tes, diperoleh nilai signifikansi $\mathrm{p}$ sebesar 0,823 , > 0,05, maka hal ini berarti hipotesis nol (H0) yang ditetapkan diterima dan hipotesis alternatif (Ha)yang ada ditolak. Sehingga hasil yang diperoleh tidak ada pengaruh pemberian aromaterapi terhadap konsentrasi siswa kelas V sekolah dasar ketika mengerjakan soal ulangan pada saat ulangan umum berlangsung.

Berdasarkan hasil tersebut diketahui bahwa tidak adanya perbedaan konsentrasi yang signifikan antara kelompok yang diberi aromaterapi dengan kelompok tanpa aromaterapi. Dari hasil tersebut maka diketahui bahwa aromaterapi belum memberikan efek yang signifikan. Jika ditinjau kembali berdasarkan teori yang ada, banyak hal yang dapat mempengaruhi konsentrasi. Hal ini terjadi karena konsentrasi dipengaruhi oleh faktor internal dan juga faktor eksternal (Susanto, 2006). Menurut Susanto (2006) faktor internal yang mempengaruhi konsentrasi pada individu antara lain kesiapan individu dalam menerima dan menghadapi ulangan umum yang berhubungan dengan kondisi fisik individu, kondisi psikologis, serta modalitas atau yang sering disebut gaya belajar. Faktor internal adalah faktor yang berada di dalam diri individu. Faktor fisik siswa mengacu pada kondisi tubuh siswa seperti kesehatan siswa dalam mengerjakan ulangan umum, memang pada saat ulangan umum berlangsung tidak ada siswa yang sakit. Selain faktor internal terdapat juga faktor eksternal yang mempengaruhi konsentrasi siswa yaitu kondisi lingkungan, dan yang lainnya. Hal tersebut dapat berasal dari dalam maupun luar diri individu.

Senada dengan Susanto, menurut Hakim (2000) konsentrasi juga dipengaruhi oleh faktor internal dan juga eksternal. Faktor internal yang mempengaruhi konsentrasi salah satunya adalah faktor psikologis yaitu intelegensi. Daya intelegensi dalam penelitian ini adalah kemampuan intelektual 
siswa. Hal ini dapat diketahui dari kemampuan siswa dalam menyerap informasi yang pada penelitian ini yaitu pelajaran. Nantinya ditransfer ketika menjawab pertanyaan-pertanyaan ulangan umum dan hasilnya dapat dilihat dengan nilai ratarata yang diperoleh baik pada kelompok eksperimen maupun kelompok kontrol.

Tabel 4. 15 Nilai rata-rata pada kelompok eksperimen dan kelompok kontrol

\begin{tabular}{|l|l|c|c|}
\hline No & \multicolumn{1}{|c|}{$\begin{array}{c}\text { Mata } \\
\text { Pelajaran }\end{array}$} & $\begin{array}{c}\text { Rata-rata nilai } \\
\text { kelompok } \\
\text { Aromaterapi }\end{array}$ & $\begin{array}{c}\text { Rata-rata nilai } \\
\text { kelompok } \\
\text { tanpa aromaterapi }\end{array}$ \\
\hline 1 & Pkn & 72 & 69,65 \\
\hline 2 & Matematika & 66 & 58 \\
\hline 3 & IPA (Sains) & 74 & 73 \\
\hline 4 & Bahasa Inggris & 73 & 73 \\
\hline
\end{tabular}

Tabel di atas menunjukkan rata-rata nilai yang diperoleh pada kelas eksperimen maupun kelas kontrol. Tidak semua nilai yang diperoleh kelompok eksperimen lebih besar dari kelompok kontrol. Pada kedua kelompok, perbedaan nilai yang cukup berbeda jauh hanya pada mata mata pelajaran matematika.

Namun, apabila dievaluasi secara lebih lanjut mengenai eksperimen yang dilakukan, pada kelompok eksperimen atau kelompok yang diberikan aromaterapi terjadi peningkatan setiap harinya yang dilihat dari rata-rata nilai yang diperoleh dari hari pertama, kedua, ketiga, hingga keempat. Sedangkan pada kelompok kontrol atau kelompok yang tidak diberikan aromaterapi, tidak terjadi peningkatan konsentrasi jika dilihat dari rata-rata perhari yang diperoleh.

Oleh sebab itu, maka peneliti melakukan wawancara singkat kepada lima orang anak pada kelompok eksperimen untuk menanyakan apa yang mereka rasakan pada saat ulangan umum berlangsung dan kelas mereka diberikan aromaterapi berupa pengharum ruangan. lima orang anak tersebut terdiri dari empat orang anak perempuan dan satu orang anak laki-laki. Tempat duduk yang mereka tempati juga tersebar, hal ini dilakukan peneliti untuk meyakinkan kembali bahwa aromaterapi telah terseberar ke seluruh ruangan kelas, tidak hanya bagian depan atau belakang kelas saja.

Pada subjek pertama yang diwawancarai mengatakan bahwa aromaterapi yang ia hirup memberikan efek tenang pada saat mengerjakan ulangan dan dapat membantu fokus menjadi lebih baik dengan bau yang harum. Aromaterapi yang dipasang di ruang kelas tidak membuatnya terganggu, malah membantunya untuk tenang dalam mengerjakan setiap soal.

Pada subjek kedua, hasil wawancara yang diperoleh hampir sama dengan sebelumnya. Subjek mengatakan dirinya menjadi lebih tenang dalam mengerjakan soal ulangan. Subjek merasa agak sedikit terganggu ketika pada jam ulangan yang kedua tidak terdapat aromaterapi di dalam kelas Hal ini bukan berarti kecanduan karena tidak terdapatgejala-gejala kecanduan seperti pusing dan mual ketika pengerjaan ulangan berlangsung tanpa aromaterapi.
Subjek ketiga mengatakan bahwa ia dapat berkonsentrasi. Menurut subjek ia merasakan adanya peningkatan nilai pada mata pelajaran yang diberikan aromaterapi pada saat ulangan umum berlangsung.

Subjek keempat merasakan aromaterapi membuat dirinya menjadi tenang. Hal tersebut diwujudkannya dengan dapat mengerjakan soal-soal menjadi lebih fokus. Begitu pula dengan subjek kelima, awalnya ia tidak menyadari bahwa aromaterapi memberikan efek yang baik untuk konsentrasinya. Setelah ia melihat nilai-nilai ulangan umum yang ada terdapat perbedaan yang pada saat menggunakan aromaterapi dan tidak. Jika dilihat dari mata pelajaran ulangan umum pada jam pertama pelajaran juga termasuk sukar.

Dari wawancara yang telah dilakukan diketahui bahwa setiap siswa merasakan adanya aromaterapi di dalam kelas pada kelompok eksperimen. Karena stimulus yang berasal dari aromaterapi diterima oleh indera penciuman yaitu hidung. Selanjutnya stimulus tersebut akan dikirim menuju ke otak.

Jika dilihat dari rata-rata yang diperoleh pada kelompok eksperimen terjadi peningkatan setiap harinya. Rata-rata yang awalnya 77,85 terus meningkat dihari berikutnya sampai pada hari terakhir rata-rata yang diperoleh sebesar 81, 40. Hanya saja selama peningkatan ini terjadi tidak membuat kedua kelompok berbeda secara signifikan. Kemungkinan hal terjadi karena proses adaptasi pada siswa sedang terjadi. Proses ini mungkin saja memerlukan waktu yang lebih panjang agar peningkatan yang terjadi pada kelompok eksperimen mencapai titik yang menjadi berbeda secara signifikan dengan kelompok kontrol.

Berdasarkan dari apa yang telah dibahas di atas, peneliti menyadari terdapat keterbatasan-keterbatasan di luar kendali peneliti. Pada saat pemberian aromaterapi, mungkin saja dapat mempengaruhi konsentrasi apabila jumlah hari yang untuk memberikan aromaterapi di dalam kelas lebih panjang, sehingga peningkatan rata-rata yang terjadi pada kelompok eksperimen dapat mencapai titik signifikansi yang nantinya dapat terlihat perbedaan antara kelompok kontrol serta kelompok eksperimen karena subjek sedang mengalami adaptasi sensoris. Jadi, semaikn lama aromaterapi diberikan maka siswa telah beradaptasi dan aromaterapi mampu berpengaruh secara efektif.

Berdasarkan hasil dan pembahasan data yang telah dibahas, maka dapat disimpulkan beberapa hal terkait dengan hasil penelitian ini, yaitu tidak ada pengaruh pemberian aromaterapi terhadap konsentrasi siswa kelas $\mathrm{V}$ sekolah dasar ketika mengerjakan soal ulangan pada saat ulangan umum berlangsung. Sehingga tidak terjadi perbedaan yang cukup signifikan antara kelompok eksperimen dengan kelompok kontrol. Hal ini disebabakan karena konsentrasi tidak hanya dipengaruhi oleh faktor ekternal, melainkan juga dipengaruhi oleh faktor internal. Pada kelompok eksperimen 


\section{N. M. Y. A. AGUSTINI DAN H. SUDHANA}

terjadi peningkatan konsentrasi setiap harinya, hanya saja tidak mencapai titik signifikan. Sedangkan, pada kelompok kontrol tidak ada perbedaan tingkatan konsentrasi setiap harinya.

Saran praktis yang dapat ditujukan kepada pihak sekolah adalah agar penelitian ini dapat dijadikan masukan sebagai salah satu alternatif pendamping ketika proses belajar mengajar dilakukan setiap harinya. Selain itu, bagi orang tua di rumah dalam melakukan pendampingan proses belajar, aromaterapi dapat digunakan sebagai salau satu alternatif yang dapat membantu siswa dalam berkonsentrasi ketika belajar sehari-hari di rumah. Saran bagi peneliti selanjutnyan adalah melakukan penelitian yang sama, tetapi dengan melakukan pembiasaan terhadap aroma terlebih dahulu serta memperpanjang hari dalam memberikan aromaterapi ketika proses eksperimen berlangsung. Hal ini agar siswa terbiasa dengan aroma yang diberikan sehingga nantinya dapat terlihat perbedaan yang signifikan sebelum dan setelah diberikan aromaterapi. Selain itu, teknik pengumpulan data lebih ditambah dengan observasi, sehingga dapat mengetahui apa saja yang tejadi ketika pemberian aromaterapi di dalam kelas. Observasi yang dilakukan dapat dengan menggunakan catatan lapangan yaitu dengan mencatat hal-hal apa saja yang terjadi ketika kelas diberi perlakuan berupa aromaterapi. Pada penelitian ini, peneliti menggunakan aromaterapi dengan aroma peppermint. Diharapkan pada penelitian selanjutnya dapat digunakan aroma yang lebih familiar dengan kehidupan sehari-hari masyarakat di Bali, khususnya pada anak-anak misalnya aroma jepun, cempaka, ataupun kenanga, namun juga memiliki manfaat untuk meningkatkan konsentrasi anak.

\section{DAFTAR PUSTAKA}

Arikunto, S. (1993). Seri manajemen sumber daya manusia Psikologi Industri. Bandung: Alumni.

Azwar, S. (2010). Dasar-dasar psikometri. Yogyakarta: Pustaka Pelajar. Azwar, S. (2010). Reliabilitas dan validitas. Yogyakarta: Pustaka Pelajar.

Campbell, D. T., \& Stanley, J. C. (1963). Experimental and quasiexperimental designs for research. Boston: Houghton Mifflin Company Boston.

Darmadi, H. (2011). Metode penelitian pendidikan. Bandung: ALFABETA. Desmita. (2011). Psikologi perkembangan peserta didik. Bandung: PT Remaja Rosdakarya.

Femina. (2010). Femina. Dipetik 30 April, 2013, dari 3 bentuk aromaterapi:www.femina.co.id/isu.wanita/kesehatan/3.bentuk.ar omaterapi/005/005/27
Hakim, T. (2000). Belajar secara efektif. Jakarta: Niaga Swadaya. Hastianingsih. (2013, Januari 14). Wolipop. Dipetik 13 Januari, 2013, dari detik.com: http://wolipop.detik.com/read/2013/01/14/084314/2141009/858/ tips- menggunakan-aromaterapi-di-rumah-agar-bebas-dari-stres

Henderson, S. (t.thn.). Aromatheraphy. Dipetik 20 February, 2012, dari Appolo Correspondence Classes: http://mansfield.com/massage/1/aroma/aroma32010.pdf

Primadiati, R. (2002). Aromaterapi: perawatan alami untuk sehat dan cantik. Jakarta: Gramedia Pustaka Utama.

Riduwan, \& Sunarto. (2009). Pengantar Statistika untuk penelitian: Pendidikan, Sosial, Komunikasi, Ekonomi, dan Bisnis. Bandung : ALFABETA.

Saifuddin, A. (2010). Reliabilitas dan validitas. Yogyakarta: Pustaka Pelajar.

Shah, Y. R., Sen, D. J., Patel, R. N., Patel, J. S., Patel, A. D., \&Prajapati, P. M. (2011).

Aromatherapy: The Doctor Of Natural Harmony Of Body \& Mind. International

Journal of Drug Development \& Research, 286-294.

Solomons, S. (2005). Using aromatherapy massage to increase shared attention behaviours in children with autistic spectrum disorders and severe learning difficulties. British Journal of Special Education , 32 (3), 127-137.

Solso, R. L., Maclin, O. H., \& Maclin, M. K. (2008). Psikologi Kognitif: edisi kedelapan . Jakarta: Penerbit Erlangga.

Sternberg, R. J. (2009). Cognitive Psychology, Fifth edition. United States: Wadsworth. Suardana, G. (2009, 03 24). detikNews. Dipetik 04 27, 2013, dari Wisata spa terbaik di dunia ada di Bali : http://news.detik.com/read/2009/03/24/162517/1104535/10/

Subastianwibowo. (2012, 13 Agustus). Dipetik 27 April, 2013, dari 10 objek wisata

terpopuler Indonesia tahun 2012: http://bacaberita.web.id/2012/08/10-objek- wisata-terpopulerindonesia-tahun-2012/

Sudirga, I. B. (2007). Widya Dharma Agama Hindu. Denpasar: Ganesa Exact.

Sugiyono. (2012). Metode penelitian kuantitatif, kualitatif, dan kombinasi (mixed method). Bandung: Alfabeta.

Sugiyono. (2012). Statistika untuk penelitian. Bandung: Alfabeta.

Suryabrata, S. (2000). Metodologi penelitian. Jakarta: PT. RajaGrafindo Persada. Susanto, H. (2006). Meningkatkan konsentrasi siswa melalui optimalisasi modalitas belajar siswa. Jurnal Pendidikan Penabur (06), 46-51.

Trihendradi, C. (2011). Langkah mudah melakukan analisis statistik menggunakan SPSS 19. Yogyakarta: ANDI.

Walgito, B. (2004). Bimbingan \& konseling (Studi dan kasus). Yogyakarta: ANDI 